\title{
Ciliate grazing on the parasite Amoebophrya sp. decreases infection of the red-tide dinoflagellate Akashiwo sanguinea
}

\author{
Mona Johansson ${ }^{1, *}$, D. Wayne Coats ${ }^{2}$ \\ ${ }^{1}$ Department of Systems Ecology, Stockholm University, Svante Arrhenius väg 21a, 10691 Stockholm, Sweden \\ ${ }^{2}$ Smithsonian Environmental Research Center, PO Box 28, Edgewater, Maryland 21037-0028, USA
}

\begin{abstract}
Parasitic dinoflagellates of the genus Amoebophrya commonly infect free-living dinoflagellates, some of which cause toxic or otherwise harmful red tides. These parasites prevent reproduction of their hosts and kill infected cells on a time scale of days. Thus, epidemic outbreaks of Amoebophrya spp. are thought to facilitate the decline of red tides by causing mass mortality of host taxa. However, little is known about biotic and abiotic factors that regulate epidemic occurrence of Amoebophrya spp. in nature. We addressed the hypothesis that grazing by ciliate microzooplankton on the infective stage of Amoebophrya sp. can regulate parasite prevalence in the bloom-forming dinoflagellate Akashiwo sanguinea. In culture, the choreotrich ciliate Strobilidium sp. rapidly ingested and digested infective dinospores of Amoebophrya sp. ex A. sanguinea. Laboratory experiments also showed that grazing by Strobilidium sp. could decrease infection of $A$. sanguinea by 70 to $80 \%$ relative to controls. Field experiments using plankton assemblages from Chesapeake Bay, USA, indicated that grazing by natural populations of ciliates may contribute to the regulation of parasitism in A. sanguinea. Thus, grazing by ciliates and other microzooplankton may indirectly influence the occurrence of red tides by limiting the spread of parasites like Amoebophrya sp.
\end{abstract}

KEY WORDS: Parasitic dinoflagellate · Harmful algal bloom • Ciliate grazing · Amoebophrya sp. · Akashiwo sanguinea · Strobilidium sp. · Chesapeake Bay

Resale or republication not permitted without written consent of the publisher

\section{INTRODUCTION}

Dinoflagellates often cause dense blooms, commonly called red tides, some of which cause toxic or otherwise harmful effects (Granéli et al. 1987, Richardson 1997, Smayda 1997). The mechanisms underlying bloom dynamics are not fully understood, but excess nitrogen $(\mathrm{N})$ and phosphorus $(\mathrm{P})$, stoichiometric ratios of $\mathrm{N}$ and $\mathrm{P}$, as well as specific hydrographic events favour bloom formation (Steidinger \& Haddad 1981, Paerl 1997). The occurrence and persistence of blooms are also determined by species-specific interactions, where the influences of competition and grazing pres-

*E-mail: mojo@system.ecology.su.se sure have been well documented (Watras et al. 1985, Jeong \& Latz 1994, Buskey et al. 1997, Kamiyama 1997, Jeong et al. 1999a,b). Recently, viruses, bacteria and eukaryotic parasites have been implicated as potentially important microbial controls of red tides (Nishitani et al. 1985, Bruning et al. 1992, Kim et al. 1998, Coats 1999, Nagasaki et al. 1999).

The endoparasitic dinoflagellate Amoebophrya ceratii has received far more attention than any other eukaryotic parasite of red-tide algae (Taylor 1968, Nishitani et al. 1985, Fritz \& Nass 1992, Coats \& Bockstahler 1994, Coats et al. 1996). Hosts infected by this parasite are unable to reproduce and eventually die (Elbrächter 1973, Cachon \& Cachon 1987), which together with the parasite's relatively short generation time $\left(<2 \mathrm{~d}\right.$ at $23^{\circ} \mathrm{C}$, Coats \& Bockstahler 1994) and 
occasionally high prevalence in nature (Nishitani et al. 1985, Coats et al. 1996) imply that A. ceratii can control dinoflagellate blooms. A. ceratii infects its hosts via dinospores, a biflagellated dispersal stage with an equivalent spherical diameter of around $5 \mu \mathrm{m}$ (Cachon 1964). The parasite grows inside the host until it occupies most of the host cell, then ruptures through the host's pellicle and transforms into a strongly motile vermiform stage that divides to produce numerous infective dinospores (Cachon 1964). Over 30 dinoflagellate species appear susceptible to infection by A. ceratii (Lebour 1925, Chatton \& Biecheler 1935, Cachon 1964, Taylor 1968, Elbrächter 1973, Nishitani et al. 1985, Jacobson 1987, Fritz \& Nass 1992, Coats \& Bockstahler 1994, Coats et al. 1996). Thus, A. ceratii has been assumed to lack host specificity. However, recent work suggests that $A$. ceratii is a species complex composed of several more or less host-specific species (Coats et al. 1996, Gunderson et al. 2000). Therefore, we use $A$. ceratii when referring to previous work incorporating that name, but use Amoebophrya sp. in the current study. The parasite studied here has been previously referred to as $A$. ceratii (Coats \& Bockstahler 1994), A. ceratii ex Gymnodinium sanguineum (Coats et al. 1996) and Amoebophrya sp. ex Gymnodinium sanguineum (Gunderson et al. 1999, 2000, Yih \& Coats 2000).

Akashiwo sanguinea (previously, Gymnodinium sanguineum) is widely distributed in Chesapeake Bay on the east coast of the USA, where it commonly causes summer red tides with concentrations sometimes close to 1000 cells ml ${ }^{-1}$ (Bockstahler \& Coats 1993a,b). The prevalence of Amoebophrya sp. in A. sanguinea of Chesapeake Bay is generally low, averaging from 0.8 to $14 \%$ for the surface mixed layer; however, localised epidemics with infection levels of 20 to $40 \%$ have been observed (Coats \& Bockstahler 1994, Coats et al. 1996). Elevated prevalence of Amoebophrya spp. is usually associated with high densities of host organisms and may be influenced by nutrient environment (Taylor 1968, Nishitani et al. 1985, Coats \& Bockstahler 1994, Yih \& Coats 2000). Coats \& Bockstahler (1994) also argued that low infection of $A$. sanguinea in the main stem of Chesapeake Bay was due to vertical separation of the hosts and parasites, as areas of high parasite prevalence typically occurred along the pycnocline, several metres below dense, lightly infected surface populations. Thus, infection by Amoebophrya sp. in Chesapeake Bay may be regulated by a variety of factors including host density, nutrient concentrations and physical conditions.

Dinospores of Amoebophrya sp. are nanoflagellates and as such are susceptible to grazing by microzooplankton. For example, dinospores of Amoebophrya ex Prorocentrum minimum are ingested by the loricate ciliate Helicostomella subulata (Maranda 2001). Thus, grazing by microzooplankton may play an important role in the ecology of Amoebophrya spp. in Chesapeake Bay, as planktonic ciliate abundances in that system are among the highest reported for coastal marine environments (Coats \& Revelante 1999). To explore that possibility, we conducted a set of laboratory and field experiments to test 3 hypotheses: (1) the ciliate Strobilidium sp. rapidly ingests and digests dinospores of Amoebophrya ex Akashiwo sanguinea; (2) grazing of dinospores by Strobilidium sp. in culture can limit parasite prevalence in A. sanguinea; and (3) infection of $A$. sanguinea is reduced in the presence of natural assemblages of microzooplankton grazers relative to levels where potential grazers are absent.

\section{MATERIALS AND METHODS}

Cultures. Cultures of Akashiwo sanguinea (Dinoflagellata) and Amoebophrya sp. (Dinoflagellata) were originally isolated from water samples taken from Chesapeake Bay on the east coast of the USA (Coats et al. 1996). Strobilidium sp. (Ciliophora) was isolated from the Rhode River ( $\left.38^{\circ} 52^{\prime} \mathrm{N}, 76^{\circ} 32^{\prime} \mathrm{E}\right)$, a small subestuary of Chesapeake Bay. Isochrysis galbana was obtained from D. Stoecker, Horn Point Lab, Cambridge, MD, USA. All cultures were maintained in $\mathrm{f} / 2-\mathrm{Si}$ medium (Guillard \& Ryther 1962) made using a base of GF/F filtered and autoclaved Bay water (15 ppt salinity).

Akashiwo sanguinea, Amoebophrya sp. and Isochrysis galbana were kept in loosely capped, 125 to $500 \mathrm{ml}$ glass Erlenmeyer flasks and maintained at $20^{\circ} \mathrm{C}$ under $100 \mu \mathrm{E} \mathrm{m}^{-2} \mathrm{~s}^{-1}$ cool-white fluorescent light with a 14:10 h light:dark cycle. A. sanguinea and I. galbana were transferred to new culture media weekly. Amoebophrya sp. was maintained by transferring aliquots of infected $A$. sanguinea to uninfected host stocks approximately every $60 \mathrm{~h}$. Cultures of Strobilidium sp. with $I$. galbana as prey were kept in $50 \mathrm{ml}$ clear plastic, tissue culture bottles and maintained at $4^{\circ} \mathrm{C}$ under cool-white fluorescent light $\left(10 \mu \mathrm{E} \mathrm{m} \mathrm{m}^{-2} \mathrm{~s}^{-1}\right)$ with a 14:10 h light:dark cycle. Strobilidium sp. was transferred to new bottles containing culture medium and I. galbana when prey density became too low to support growth of the ciliate (weekly to biweekly).

Culture experiments were conducted under growth conditions used to maintain Akashiwo sanguinea and Amoebophrya sp. Strobilidium sp. was acclimated to those conditions for at least $2 \mathrm{~h}$ prior to conducting experiments.

Feeding of Strobilidium sp. on dinospores of Amoebophrya sp. Ingestion of Amoebophrya sp. dinospores by Strobilidium sp. was examined in a time-series, batch-culture experiment. Dinospores of Amoebophrya 
sp. were separated from infected host culture by size fractionation using a $12 \mu \mathrm{m}$ pore size Nuclepore filter. Harvested dinospores were then added to 21 vials of $7 \mathrm{ml}$ that contained a mixture of Strobilidium sp. and Isochrysis galbana. As controls, filtrate from infected host culture (Whatman GF/F filters) was added to 14 vials containing the same mixture of Strobilidium sp. and I. galbana. Initial, target density for Strobilidium sp. was set at 30 cells ml $^{-1}$, while that of $I$. galbana and dinospores of Amoebophrya sp. were $8 \times 10^{4}$ and $5 \times$ $10^{3}$ cells $\mathrm{ml}^{-1}$, respectively. At each sampling time $\left(t_{\min }=t_{0}, t_{5}, t_{10}, t_{15}, t_{30}, t_{60}, t_{120}\right), 3$ samples and 2 controls were fixed with $\mathrm{CaCO}_{3}$ buffered formaldehyde ( $2 \%$ final concentration). Fixed samples were poured into $5 \mathrm{ml}$ counting chambers and examined using an inverted epifluorescence microscope (Leitz Diavert microscope, 400×). For each sample, 20 Strobilidium sp. were examined for the presence of food vacuoles containing green-fluorescent dinospores of Amoebophrya. All samples were counted immediately after fixation (within $30 \mathrm{~min}$, as recommended by Coats \& Bockstahler 1994) to avoid fading of dinospore fluorescence.

Effect of Strobilidium sp. on infection of Akashiwo sanguinea. The influence of Strobilidium sp. on infection of A. sanguinea by dinospores of Amoebophrya sp. was tested in a separate batch-culture experiment. Uninfected A. sanguinea and dinospores of Amoebophrya sp. were added to $50 \mathrm{ml}$ clear plastic, tissue culture bottles to yield a host density of $1000 \mathrm{ml}^{-1}$ and 3 different dinospore:host ratios, those being 5:1, 1:1 and 1:5. Each dinospore:host treatment was replicated 6 times. Culture of Strobilidium sp. containing Isochrysis galbana was added to 3 of the bottles of each dinospore:host ratio, to final densities of $\sim 60 \mathrm{cells} \mathrm{ml}^{-1}$ and $\sim 30000$ cells ml ${ }^{-1}$ for ciliates and I. galbana, respectively. As a control, the remaining bottles received an equivalent volume of filtrate that was obtained by gravity filtration of Strobilidium sp. culture through an $8 \mu \mathrm{m}$ Nuclepore filter to remove the ciliates, but not the I. galbana. Bottles were incubated as above, with $5 \mathrm{ml}$ samples removed from each bottle after $24 \mathrm{~h}$ and fixed with $\mathrm{CaCO}_{3}$ buffered formaldehyde ( $2 \%$ final concentration). Samples were examined by epifluorescence microscopy as above, with $100 \mathrm{~A}$. sanguinea from each sample scored as being either infected (containing green-fluorescing parasites) or uninfected. Five ml samples from each bottle were also fixed with modified Bouin's solution (Coats \& Heinbokel 1982) at the start of the experiment and after $24 \mathrm{~h}$ for counting of I. galbana, A. sanguinea and Strobilidium sp. A. sanguinea and Strobilidium sp. were counted with a Zeiss microscope in $1 \mathrm{ml}$ Sedgwick-Rafter chambers $(100 \times)$ and I. galbana in $0.1 \mathrm{ml}$ Palmer-Maloney chambers (250×). The whole chamber was scanned for Strobilidium sp. and arbitrarily selected fields of view for A. sanguinea and $I$. galbana until at least 100 cells were counted. Growth rates of I. galbana with and without Strobilidium sp. as well as growth rates of Strobilidium sp. were calculated assuming exponential growth:

$$
\mu=\left(\ln N_{t}-\ln N_{0}\right) t^{-1}
$$

where $\mu$ is growth rate $\left(\mathrm{h}^{-1}\right), N_{0}$ and $N_{t}$ are cell concentration at the start and end of the experiment, respectively, and $t$ is the duration of the experiment $(24 \mathrm{~h})$.

Clearance rates for Strobilidium sp. $\left(\mu \mathrm{l}\right.$ ciliate $\left.^{-1} \mathrm{~h}^{-1}\right)$ were calculated using equations of Frost (1972) as modified by Heinbokel (1978) to adjust for growth of the predator.

Effect of natural plankton assemblages on infection of Akashiwo sanguinea. The impact of natural plankton assemblages on infection of $A$. sanguinea by dinospores of Amoebophrya sp. was tested in experiments conducted during August 2000 using surface water from 6 locations in Chesapeake Bay: August 19, Stn 1, $37^{\circ} 44^{\prime} \mathrm{N}, 76^{\circ} 11^{\prime} \mathrm{W}$; August 21, Stns 2, 4 and 5, $37^{\circ} 58^{\prime} \mathrm{N}, 76^{\circ} 07^{\prime} \mathrm{W}, 38^{\circ} 10^{\prime} \mathrm{N}, 76^{\circ} 07^{\prime} \mathrm{W}$, and $38^{\circ} 10^{\prime} \mathrm{N}$, $76^{\circ} 19^{\prime} \mathrm{W}$, respectively; August 30, Stns 3 and 6, $38^{\circ} 02^{\prime} \mathrm{N}, 76^{\circ} 19^{\prime} \mathrm{W}$ and $38^{\circ} 19^{\prime} \mathrm{N}, 76^{\circ} 27^{\prime} \mathrm{W}$, respectively (Fig. 1). All 6 locations were in the mesohaline portion of the Bay, with salinity at the stations ranging from 13.0 to $14.9 \mathrm{ppt}$. Uninfected A. sanguinea and harvested dinospores of Amoebophrya sp. were added to water samples to yield final concentrations of 100 and 500 or 1000 cells ml ${ }^{-1}$, respectively. As a control, A. sanguinea and dinospores of Amoebophrya sp. were added at the same concentrations to water samples passed through Whatman GF/F filters to remove potential grazers. To determine background infection of A. sanguinea due to naturally occurring Amoebophrya sp., host cells, but not dinospores, were added to field samples at the same concentrations used above.

For each experiment, replicates (3 to 5) for treatments, controls and background infection were incubated in $50 \mathrm{ml}$ clear plastic, tissue culture bottles for 24 to $36 \mathrm{~h}$. Bottles for the first experiment (Stn 1) were incubated in a flowing seawater bath on the deck of the RV 'Cape Henlopen'. The water bath maintained ambient surface water temperature $\left(24.7\right.$ to $\left.25.6^{\circ} \mathrm{C}\right)$ and was shaded with neutral density screening to provide a light level of $130 \mu \mathrm{E} \mathrm{m} \mathrm{m}^{-2} \mathrm{~s}^{-1}$ ( 10\% of surface irradiance). Bottles for all subsequent experiments were maintained under conditions used for laboratory experiments. At the beginning and end of experiments, a $20 \mathrm{ml}$ sample was taken from each bottle and fixed with modified Bouin's solution (Coats \& Heinbokel 1982). Fixed samples were processed by the quantitative protargol staining technique of Montagnes \& Lynn (1993) and 100 A. sanguinea from each sample were scored as infected or uninfected following 


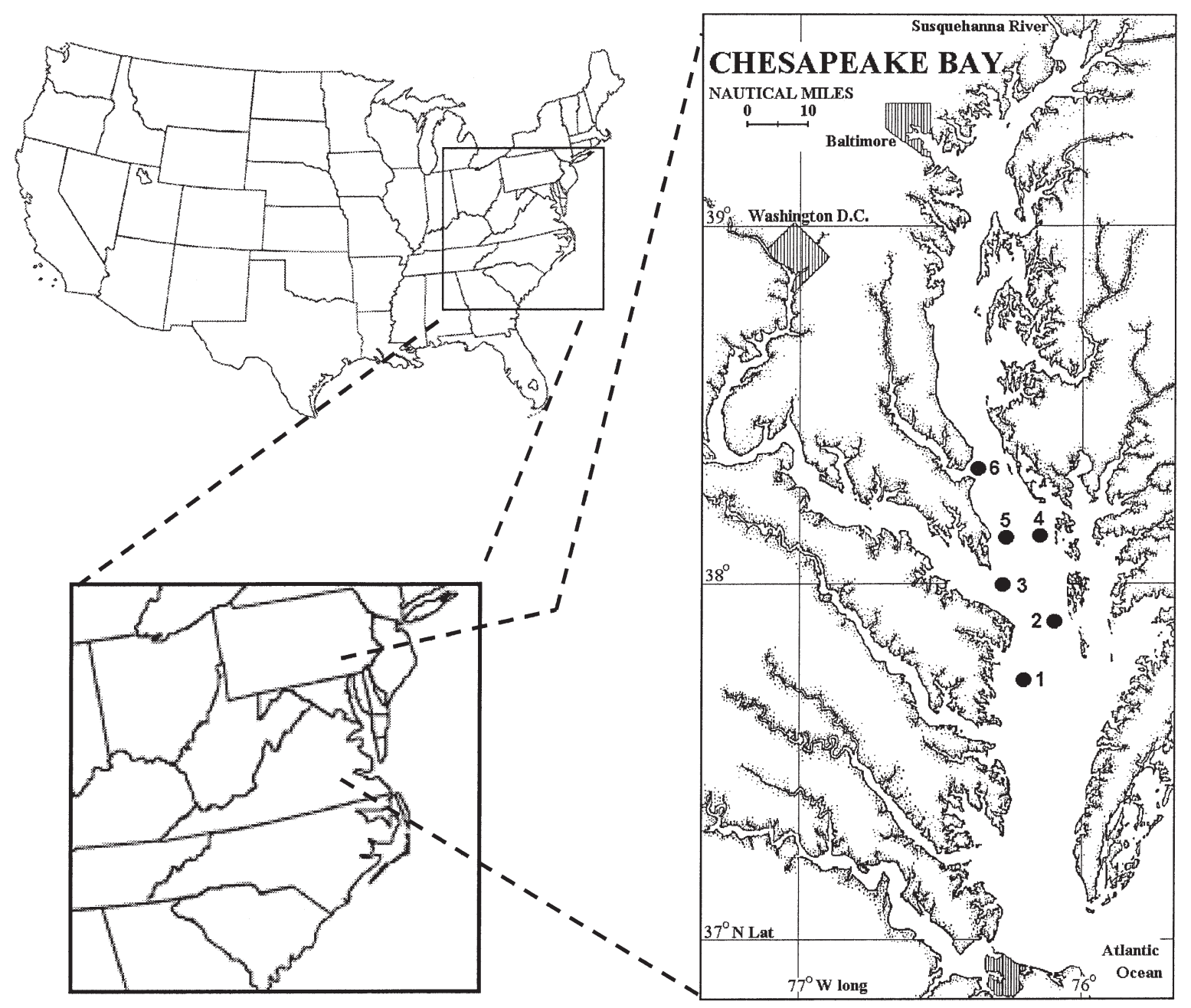

Fig. 1. Chesapeake Bay estuary showing stations where water was collected for experiments

established procedures (Coats \& Bockstahler 1994). Abundance of ciliates and A. sanguinea were determined using protargol stained preparations of time zero samples. Stained preparations were scanned using Zeiss optics $(400 \times)$ and ciliates present in arbitrarily selected fields of view were tallied by genus, with species identification whenever possible, until at least 100 ciliates were counted. For abundance of $A$. sanguinea, the whole filter was scanned at $200 \times$.

Statistical analysis. Data are reported in the text as mean \pm SE of the mean. The effect of Strobilidium sp. on infection of Akashiwo sanguinea was analysed in a 2-way analysis of variance (ANOVA) with dinospore: host ratio and presence/absence of Strobilidium sp. as factors. Data for percent $A$. sanguinea infected by Amoebophrya sp. were arcsine square-root transformed prior to completing the ANOVA. Growth rates of Strobilidium sp. in the different dinospore:host treatments were compared with a 1-way ANOVA. The effect of natural plankton assemblages on infection of $A$. san- guinea was tested with a 2-way ANOVA, with station number and presence/absence of natural plankton assemblages used as factors. Arcsine square-root transformation of data for percent $A$. sanguinea infected in the field study failed to give equal variance, thus data were rank transformed prior to the ANOVA. Linear correlation analysis (Pearson's product-moment) was used to explore relationships between ciliate abundance in field samples and (1) the percent infected naturally occurring $A$. sanguinea and (2) observed decrease in parasitism of added $A$. sanguinea in whole water treatments relative to predator-free controls. Linear correlation analysis was also used to test the salinity in field water samples versus (1) ciliate cell numbers, (2) naturally occurring $A$. sanguinea cell numbers, (3) infection of naturally occurring A. sanguinea (i.e. parasite prevalence at the time samples were collected), (4) infection of added $A$. sanguinea in whole water treatment, (5) infection of added A. sanguinea in GF/F filtered treatment and (6) infection of 

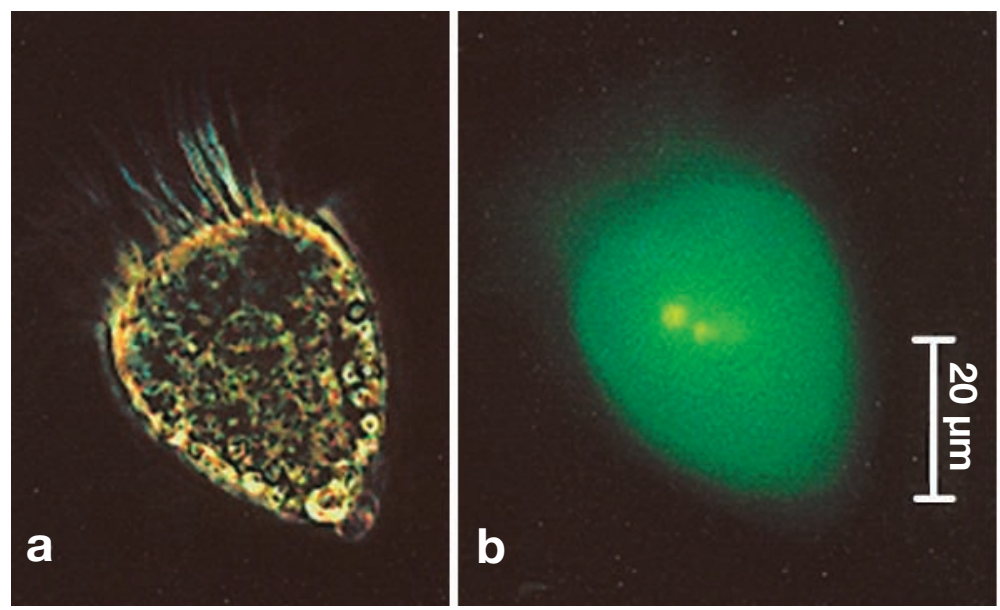

Fig. 2. Strobilidium sp. incubated with Isochrysis galbana and dinospores of Amoebophrya sp. for 60 min. (a) Phase contrast microscopy, (b) epifluorescence microscopy. Original magnification $400 \times$

added $A$. sanguinea by naturally occurring parasites (background infection). Statistical comparisons were made using 'Statistica' software (StatSoft).

\section{RESULTS}

\section{Feeding of Strobilidium sp. on dinospores of Amoebophrya sp.}

Strobilidium sp. incubated in the presence of mixed prey consisting of Isochrysis galbana and dinospores of Amoebophrya sp. quickly acquired a green fluorescence similar to that of the parasite (Fig. 2a,b). The

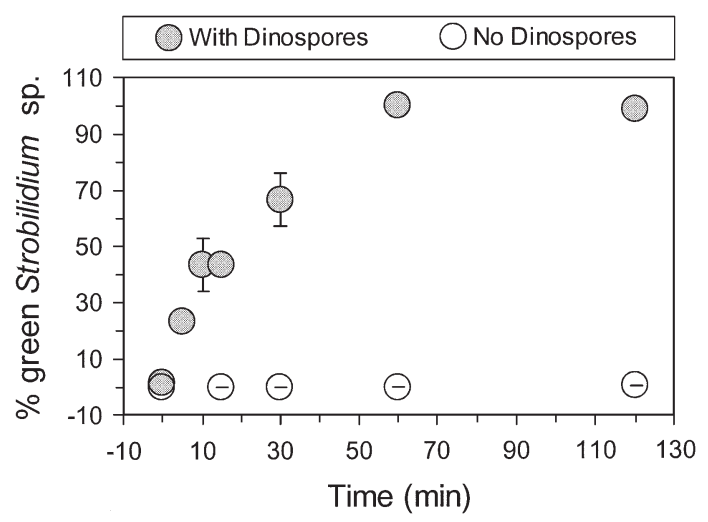

Fig. 3. Strobilidium sp. Percentage exhibiting green fluorescence when incubated in the presence of dinospores from Amoebophrya sp. (closed symbols) or dinospore filtrate (open symbols); error bars indicate SE. Ciliates offered dinospores as prey acquired a green cytoplasmic fluorescence within minutes (see Fig. 2b). Ciliates in controls had no green colour green colour was evenly distributed throughout the ciliate cytoplasm, with bright-green fluorescing food vacuoles indicative of recently ingested dinospores rarely detected. The percentage of ciliates exhibiting green fluorescence increased hyperbolically from $23 \pm 1.7 \%$ after $5 \mathrm{~min}$ to saturation at $100 \%$ by 60 min (Fig. 3). Strobilidium sp. in control incubations (i.e. I. galbana plus dinospore filtrate) failed to show any indication of green fluorescence.

\section{Effect of Strobilidium sp. on infection of Akashiwo sanguinea}

The percent of Akashiwo sanguinea infected by Amoebophrya sp. at the 3 different dinospore:host ratios was significantly lower when Strobilidium sp. was present ( $\mathrm{p}<$ $0.001, F_{1,12}=123$; Fig. 4). Two-way ANOVA indicated that inoculum size (i.e. dinospore:host ratio) and presence/absence of ciliates had significant effects on parasite prevalence $\left(\mathrm{p}<0.001, F_{2,12}=89, \mathrm{p}<0.001, F_{1,12}=\right.$ 123); however, there was also a significant interaction between inoculum size and presence/absence of ciliates $\left(\mathrm{p}=0.001, F_{2,12}=12\right)$. Pairwise comparison (Tukey test) showed that the presence of ciliates significantly decreased infection level relative to ciliate-free controls for each dinospore:host ratio $\left(\mathrm{p}<0.001, F_{1,4}=98\right.$, $\mathrm{p}<0.001, F_{1,4}=38$ for 5:1 and 1:1 dinospore:host ratios; $\mathrm{p}=0.01, F_{1,4}=9.5$ for 1:5 dinospore:host ratio). Relative to ciliate-free controls, parasite prevalence decreased

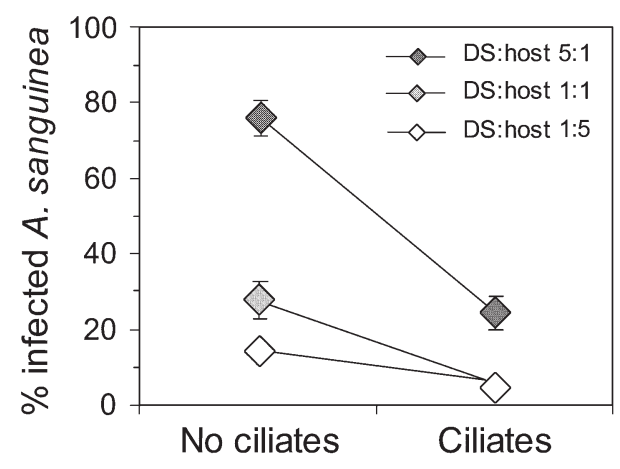

Fig. 4. Akashiwo sanguinea. Percentage infected by dinospores of Amoebophrya sp. when incubated in the presence (Ciliates) or absence (No ciliates) of Strobilidium sp.: DS = 5000, 1000, or 200 dinospores $\mathrm{ml}^{-1}$; host $=1000$ Akashiwo sanguinea $\mathrm{ml}^{-1}$; error bars indicate SE. Parasite prevalence was significantly lower for each dinospore:host ratio when ciliates were present $(p<0.05)$ 
by $67 \%$ in treatments with dinospore:host ratios of $5: 1$ and $1: 5$, and by $83 \%$ when dinospore:host ratio was $1: 1$.

Abundance of Strobilidium sp. increased in each treatment during the $24 \mathrm{~h}$ incubation (Table 1), with growth rates $\left(0.0072\right.$ to $\left.0.012 \mathrm{~h}^{-1}\right)$ not differing among treatments $\left(\mathrm{p}=0.45, F_{2,6}=0.90 ; 1\right.$-way ANOVA). Abundance of Isochrysis galbana increased in the absence of ciliates, but decreased when ciliates were present (Table 1). The growth of I. galbana averaged $0.011 \pm 0.015 \mathrm{~h}^{-1}$ in treatments without ciliates and $-0.019 \pm 0.014 \mathrm{~h}^{-1}$ when ciliates were present. These data indicate that Strobilidium sp. was grazing I. galbana at clearance rates of 10 to $31 \mu$ ciliate ${ }^{-1} \mathrm{~h}^{-1}$, with a mean of $20 \pm 6 \mu$ ciliate ch $^{-1}$.

\section{Effect of natural plankton assemblages on infection of Akashiwo sanguinea}

The effect of natural plankton assemblages on parasitism of Akashiwo sanguinea was tested by adding A. sanguinea and dinospores of Amoebophrya sp. to whole water samples from 6 different stations in the mesohaline part of the Chesapeake Bay (Fig. 1). As a control, A. sanguinea and dinospores of Amoebophrya sp. were added to GF/F filtered water from the same stations. Two-way ANOVA indicated that mean parasite prevalence following $24 \mathrm{~h}$ incubation differed significantly among stations and by presence/absence of natural plankton assemblages ( $\mathrm{p}<0.001, F_{5,34}=98, \mathrm{p}<$ $\left.0.001, F_{1,34}=29\right)$; however, there was also a significant interaction between the 2 factors ( $p=0.001, F_{5,34}=5.3$ ). Pairwise comparison (Tukey test) showed that Stns 2, 4, 5 and 6 had statistically lower parasite prevalence in whole water treatments relative to controls $(\mathrm{p}<0.05$, $F_{1,4}=4.5, F_{1,6}=16, F_{1,4}=4.8, F_{1,8}=23$ ), while treatments and controls did not differ at Stns 1 and 3 ( p = 0.07, $\left.F_{1,4}=3.5, \mathrm{p}=0.09, F_{1,8}=3.0\right)$. Addition of $A$. sanguinea but not dinospores of Amoebophrya sp. resulted in background infection levels ranging from 0 to $4 \%$ (Table 2 ).

Ciliate abundance and species composition varied among stations, with highest densities at Stn 4 in the middle of the Bay and lowest densities at Stn 3 near the mouth of the Potomac River (Table 2). Choreotrich ciliates were numerically predominant at all stations, with tintinnids being more abundant than aloricate taxa. Data for parasite prevalence normalised to control values (i.e. percent reduction in infected hosts for

Table 1. Isochrysis galbana growth rates $\left(\mathrm{h}^{-1}\right)$ and Strobilidium sp. growth and clearance rates in 3 different dinospore concentrations. There was no difference $\left(F_{2,6}=0.90, \mathrm{p}=0.45\right)$ in growth rate of Strobilidium sp. in the different dinospore concentrations, indicating food saturation in all treatments. Growth rates of $I$. galbana were lower in treatments with Strobilidium sp., indicating grazing of the ciliates, wherefore we calculated a clearance rate $\left(\mu l\right.$ ciliate $\left.^{-1} \mathrm{~h}^{-1}\right)$ for $I$. galbana. DS $=$ dinospores, host $=$ Akashiwo sanguinea. Host concentrations were 1000 cells ml-1 in all treatments and dinospore abundance was increased or decreased to achieve the ratio

\begin{tabular}{|lcccc|}
\hline $\begin{array}{l}\text { DS:host } \\
\text { ratio }\end{array}$ & $\begin{array}{l}\text { Isochrysis galbana growth rate }\left(\mathrm{h}^{-1}\right) \pm \mathrm{SE} \\
\text { Without } \\
\text { Strobilidium sp. }\end{array}$ & $\begin{array}{c}\text { With } \\
\text { Strobilidium sp. }\end{array}$ & $\begin{array}{c}\text { Growth rate } \\
\left(\mathrm{h}^{-1}\right) \pm \mathrm{SE}\end{array}$ & $\begin{array}{c}\text { Strobilidium sp. } \\
\text { Clearance rate } \\
\left(\mathrm{ml} \mathrm{ciliate}^{-1} \mathrm{~h}^{-1}\right) \pm \mathrm{SE}\end{array}$ \\
\hline $5: 1$ & $0.012 \pm 0.009$ & $-0.034 \pm 0.016$ & $0.011 \pm 0.0036$ & $31 \pm 11$ \\
$1: 1$ & $0.022 \pm 0.022$ & $-0.0085 \pm 0.016$ & $0.012 \pm 0.0015$ & $20 \pm 12$ \\
$1: 5$ & $-0.0015 \pm 0.013$ & $-0.015 \pm 0.0039$ & $0.0072 \pm 0.0029$ & $10 \pm 3$ \\
\hline
\end{tabular}

Table 2. Akashiwo sanguinea. Percentages of parasite infection in the presence and absence of field populations of ciliates at 6 stations in Chesapeake Bay (Fig. 1). *A significant reduction in percent infected A. sanguinea in the presence of ciliates (p < 0.05). Infection of $A$. sanguinea by naturally occurring parasites is listed as background infection. Total ciliate numbers (cells $\mathrm{ml}^{-1}$ ) found at the different stations are listed together with Choreotrichia (Choreo) and Tintinnina abundances. Cell concentrations and infection levels are also given for natural populations of A. sanguinea (Natural A. sang.)

\begin{tabular}{|c|c|c|c|c|c|c|c|c|c|c|}
\hline \multirow[t]{2}{*}{ Stn } & \multirow{2}{*}{$\begin{array}{l}\text { Salinity } \\
\text { (ppt) }\end{array}$} & \multicolumn{4}{|c|}{$\%$ infected $A$. sanguinea } & \multicolumn{3}{|c|}{ No. of ciliates (cells ml ${ }^{-1}$ ) } & \multicolumn{2}{|c|}{ Natural A. sang. } \\
\hline & & $\begin{array}{l}\text { With } \\
\text { ciliates }\end{array}$ & $\begin{array}{c}\text { No } \\
\text { ciliates }\end{array}$ & $\begin{array}{l}\text { Background } \\
\text { infection }\end{array}$ & $\begin{array}{c}\text { Reduction } \\
(\%)\end{array}$ & Total & Choreo & Tintinnina & $\begin{array}{l}\text { Cells } \\
\left(\mathrm{ml}^{-1}\right)\end{array}$ & $\begin{array}{c}\text { Infected } \\
(\%)\end{array}$ \\
\hline 1 & 14.8 & $15 \pm 0.6$ & $52 \pm 5$ & $4 \pm 2$ & $71 \pm 2^{*}$ & 56 & 51 & 36 & 1.5 & 8.2 \\
\hline 2 & 14.9 & $3 \pm 0.6$ & $7 \pm 1$ & $0.3 \pm 0.3$ & $59 \pm 5^{*}$ & 90 & 66 & 49 & 1.6 & 13 \\
\hline 3 & 14.7 & $85 \pm 8$ & $76 \pm 4$ & $1 \pm 0.4$ & $-12 \pm 6$ & 33 & 19 & 11 & 0.2 & 0 \\
\hline 4 & 14.5 & $4 \pm 1$ & $11 \pm 2$ & $0 \pm 0$ & $65 \pm 5^{*}$ & 218 & 199 & 196 & 4.1 & 7.7 \\
\hline 5 & 13.1 & $9 \pm 1$ & $16 \pm 3$ & $0.3 \pm 0.3$ & $32 \pm 26$ & 132 & 85 & 74 & 71 & 3 \\
\hline 6 & 13.0 & $72 \pm 4$ & $95 \pm 2$ & $0.6 \pm 0.5$ & $24 \pm 6^{*}$ & 72 & 25 & 11 & 1.6 & 0 \\
\hline
\end{tabular}




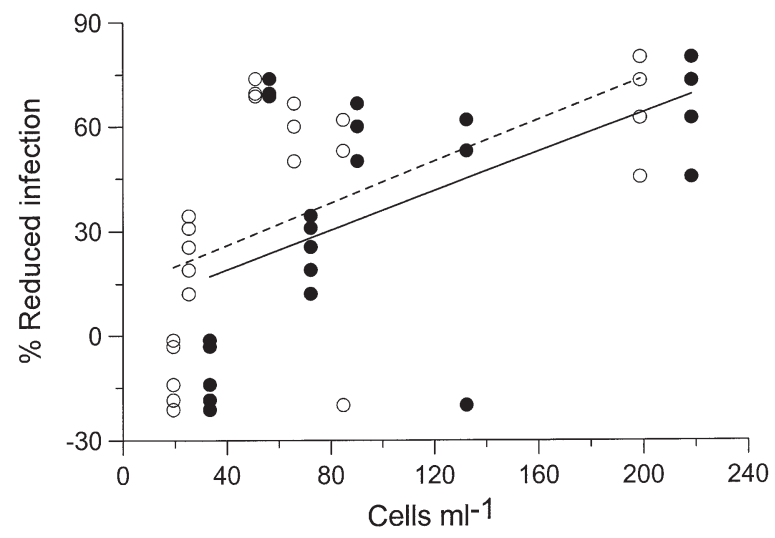

Fig. 5. Akashiwo sanguinea. Correlation between percent reduced infection and total ciliate abundance ( $\bullet$ and - ), as well as choreotrich ciliate abundance ( 0 and -...--) for experiments using plankton assemblages from Chesapeake Bay. Both correlations were significant (total ciliates: $p=0.01$, $r^{2}=0.28$; Choreotrichia: $p=0.006, r^{2}=0.31$ )

treatments relative to controls) increased with increasing ciliate abundance; correlation analysis revealed a significant relationship between the reduction in parasitism and total ciliate abundance $\left(p=0.01, r^{2}=0.28\right)$ and choreotrich densities $\left(p=0.006, r^{2}=0.31\right)$, see Fig. 5.

The abundance of Akashiwo sanguinea at the different stations before addition of cultured $A$. sanguinea had a range of 0.2 to 71 cells $\mathrm{ml}^{-1}$, and the percentage infection ranged between 0 and $13 \%$ (Table 2). There was no correlation between the ciliate abundance and the percent infected naturally occurring $A$. sanguinea $\left(\mathrm{p}=0.57, \mathrm{r}^{2}=0.09\right)$.

Salinity at Stns 1 to 6 ranged between 13.0 and 14.9 ppt (Table 2). There were no significant correlations between salinity and any of the tested parameters (abundance of ciliates $\mathrm{p}=0.55, \mathrm{r}^{2}=0.10$; abundance of naturally occurring Akashiwo sanguinea $\mathrm{p}=0.21$, $\mathrm{r}^{2}=0.36$; percentage of infected naturally occurring A. sanguinea: $\mathrm{p}=0.19, \mathrm{r}^{2}=0.39$; infection of added A. sanguinea in whole water treatment: $\mathrm{p}=0.68, \mathrm{r}^{2}=$ 0.047; infection of $A$. sanguinea in GF/F filtered treatment: $\mathrm{p}=0.59, \mathrm{r}^{2}=0.078$; background infection: $\mathrm{p}=$ $0.50, \mathrm{r}^{2}=0.12$ ).

\section{DISCUSSION}

A variety of abiotic factors including light environment, temperature and nutrient concentrations are known to alter the success of eukaryotic algal parasites (Bruning \& Ringelberg 1987, Bruning 1991a,b, Yih \& Coats 2000); however, little is known about biological interactions that influence these host-parasite systems. Results reported here indicate that biotic factors like predation can play an important role in regulating the transmission of eukaryotic parasites to algal hosts. Our laboratory experiments demonstrate that the ciliate Strobilidium sp. readily ingests and digests infective dinospores of the parasitic dinoflagellate Amoebophrya sp., with removal of these infective cells being sufficient to reduce parasite prevalence in cultures of the dinoflagellate host Akashiwo sanguinea. Furthermore, field experiments indicate that grazing pressure on dinospores from natural microzooplankton assemblages can regulate parasite prevalence in $A$. sanguinea. By limiting the prevalence of eukaryotic parasites, ciliates may reduce mortality of dinoflagellates and thus enhance formation and/or persistence of red tides.

When exposed to dinospores of Amoebophrya sp., Strobilidium sp. quickly acquired a green fluorescence similar in colour to that of the parasite; however, discrete dinospores were rarely detected inside the ciliate's food vacuoles. The absence of green fluorescence in ciliates exposed to dinospore filtrate indicates that the change in fluorescent properties of Strobilidium sp. resulted from direct interaction with dinospores, rather than accumulation of dissolved substances released into the medium by the parasite. These observations suggest that dinospores of Amoebophrya sp. are rapidly ingested and digested by Strobilidium sp., with the parasite's fluorochrome being quickly dispersed into the ciliate's cytoplasm. Alternatively, dinospores may actively attack Strobilidium sp., penetrating into the ciliate's cytoplasm and perhaps initiating infections. However, several lines of evidence suggest that this is not the case. First, parasites belonging to the Amoebophrya ceratii complex have only been reported from dinoflagellate hosts (Cachon 1964, Coats 1999), with the strain used here being specific to Akashiwo sanguinea (Coats et al. 1996). Second, Amoebophrya spp. prevent reproduction of their hosts (Elbrächter 1973, Coats \& Bockstahler 1994), but Strobilidium sp. exposed to parasites in our experiments continued to reproduce at a rapid rate. Third, the green fluorescence observed in Strobilidium sp. was not localised within a discrete region as is characteristic of Amoebophrya sp. infections, nor were easily recognised stages of the infection cycle apparent inside any of the ciliates. Thus, observed differences in infection of $A$. sanguinea in the presence and absence of Strobilidium sp. most likely reflect the influence of ciliate-dinospore grazing interactions.

In prey mixtures consisting of Isochrysis galbana and dinospores of Amoebophrya sp., grazing by Strobilidium sp. reduced infection of Akashiwo sanguinea by 70 to $80 \%$ during a $24 \mathrm{~h}$ incubation. The green fluorescence of Amoebophrya sp. life-history stages, including dinospores, fades quickly after fixation (Coats \& Bockstahler 1994), and thus we were unable to directly 
estimate grazing of Strobilidium sp. on dinospores using prey disappearance over time. However, we were able to determine that Strobilidium sp. cleared I. galbana at about $20 \mu \mathrm{l}$ ciliate ${ }^{-1} \mathrm{~h}^{-1}$ during the experiment, a clearance rate that falls within the range (11 to $43 \mu \mathrm{l}$ ciliate ${ }^{-1} \mathrm{~h}^{-1}$ ) previously reported for Strobilidium sp. (Lessard \& Swift 1985, Jonsson 1986, Kivi \& Setälä 1995). Strobilidium species are filter feeders. They can, however, discriminate/select certain prey, although this selection is lower under saturated food conditions (Christaki et al 1998). Levels of I. galbana used in our experiment were high and probably above saturating food levels. Assuming that Strobilidium sp. cleared I. galbana and dinospores of Amoebophrya sp. at equal rates, then initial ciliate densities in our experiment ( 61 to 67 cells ml $^{-1}$ ) could have removed 120 to $130 \%$ of the dinospores in the first hour of the incubation. Since infection of A. sanguinea by dinospores of Amoebophrya sp. can take a few hours to reach saturation (D .W. Coats pers. obs.), removal of dinospores by Strobilidium sp. could easily account for observed reductions in parasite prevalence in treatments relative to ciliate-free controls.

Ciliate populations of Chesapeake Bay represent among the most abundant and diverse assemblages reported for temperate coastal environments (Coats \& Revelante 1999). Peak densities typically occur in late spring to early summer when mean water column abundance can exceed 50 cells ml-1 ${ }^{-1}$ However, ciliates are abundant throughout the summer, with mean densities of 20 to $30 \mathrm{ml}^{-1}$ integrated over the water column. Choreotrich taxa that feed on nano-sized food particles often form a major portion of the ciliate community in the Bay during summer (Dolan 1991, Coats \& Revelante 1999) and may exert considerable pressure on prey similar in size to dinospores of Amoebophrya sp. Ciliate abundance in our field experiments ranged from 30 to $>200 \mathrm{ml}^{-1}$, with choreotrich taxa forming 35 to $91 \%$ of the community. Since most of the ciliates were potential grazers of Amoebophrya sp. dinospores, it is not surprising that infection of Akashiwo sanguinea was 3 to $45 \%$ lower in whole water treatments compared to predator-free controls. We also found a correlation between reduced parasite prevalence and total ciliate abundance as well as choreotrich abundance, which further supports the argument that ciliates were grazing on the dinospores. However, we cannot rule out that factors other than ciliate grazing influenced parasite prevalence in the whole water treatments. Heterotrophic microflagellates or micrometazoa were not considered in our study, but are often abundant in Chesapeake Bay (Brownlee \& Jacobs 1987, Lessard 1991) and may have contributed to observed differences in parasite prevalence between whole water treatments and predator-free controls. Alternatively, differences in water quality among stations may have influenced results. For example, suspended particulates may have aggregated dinospores of Amoebophrya sp. in treatments but not in the GF/F filtered, prey-free controls, with differences in particle load among stations altering transmission of infections to A. sanguinea. Differences in salinity among stations, however, appeared to have little or no influence on experimental results.

Infection of Akashiwo sanguinea by Amoebophrya sp. in Chesapeake Bay shows considerable spatial, seasonal and interannual variation (Coats \& Bockstahler 1994, Coats et al. 1996). Horizontal patchiness in parasite prevalence has been linked to variations in host abundance, while vertical separation of heavily infected and lightly infected populations of $A$. sanguinea has been attributed to parasite-induced changes in host behaviour (Coats \& Bockstahler 1994). Grazing of dinospores by ciliates and other microzooplankton may also contribute to variations in parasite prevalence, thereby promoting vertical and horizontal patchiness. For example, Dolan \& Coats (1990) reported maximum densities of ciliates in near surface waters of Chesapeake Bay in summer and early fall. Thus, grazing pressure on dinospores of Amoebophrya sp. may decrease with depth, allowing greater transmission of parasites and higher infection levels in subsurface water as previously reported for $A$. sanguinea. Interestingly, we did not find a correlation between ciliate abundance and parasite prevalence in naturally occurring A. sanguinea; however, our ability to detect a relationship was likely influenced by small sample size (i.e. 6 stations). Abundance and infection levels of natural $A$. sanguinea, however, were quite low, ranging from 0.2 to 71 cells ml ${ }^{-1}$ and 0 to $13 \%$, respectively. It is possible that factors other than ciliate grazing pressure (e.g. dinospore longevity and parasite-host encounter probability) may regulate transmission of infections when host and parasite populations are depressed.

In conclusion, our laboratory and field experiments suggest that microbial interactions can help explain population dynamics of red-tide dinoflagellates. Eukaryotic parasites like Amoebophrya spp. and Parvilucifera infectans (Norén et al. 1999) clearly affect the occurrence of red tides to varying extents. Some of this variation may result from the influence of ciliate grazing pressure on the survival of dispersal, infective lifehistory stages of parasites that infect red-tide algae. Interestingly, many red-tide dinoflagellates are mixotrophic and are capable of exerting considerable grazing pressure on ciliates (Bockstahler \& Coats 1993a,b, Smalley et al. 1999). This raises the possibility that epidemics of Amoebophrya spp., and perhaps other parasites, occur when grazing pressure from red-tide 
dinoflagellates reduce ciliate abundance sufficiently to release grazing controls on infective life-history stages. Thus, trophic interactions among mixotrophic dinoflagellates, their parasites and ciliate microzooplankton may promote successional shifts in red-tide dinoflagellate communities.

Acknowledgements. This work was supported by a NSF grant (OCE-9730695) to D.W.C., a work/learn internship program at the Smithsonian Environmental Research Center awarded to M.J., and a travel grant to M.J. from the Stockholm Marine Research Centre (SMF). We thank Sean Cooney for technical assistance and Gabriela W. Smalley for cultures of Strobilidium sp.

\section{LITERATURE CITED}

Bockstahler KR, Coats DW (1993a) Spatial and temporal aspects of mixotrophy in Chesapeake Bay dinoflagellates. J Eukaryot Microbiol 40:49-60

Bockstahler KR, Coats DW (1993b) Grazing of the mixotrophic dinoflagellate Gymnodinium sanguineum on ciliate populations of Chesapeake Bay. Mar Biol 116:477-487

Brownlee DC, Jacobs F (1987) Mesozooplankton and microzooplankton in the Chesapeake Bay. In: Majumdar SK, Hall LW Jr, Austin HM (eds) Contaminant problems and management of living Chesapeake Bay resources. Pennsylvania Academy of Sciences, Easton, p 217-269

Bruning K (1991a) Infection of the diatom Asterionella by a chytrid. I. Effect of light on reproduction and infectivity of the parasite. J Plankton Res 13(1):103-117

Bruning K (1991b) Effects of temperature and light on the population dynamics of the Asterionella-Rhizophydium association. J Plankton Res 13(4):707-719

Bruning K, Ringelberg J (1987) The influence of phosphorus limitation of the diatom Asterionella formosa on the zoospore production of its fungal parasite Rhizophydium planktonicum. Hydrobiol Bull 21(1):49-54

Bruning K, Lingeman R, Ringelberg J (1992) Estimating the impact of fungal parasites on phytoplankton populations. Limnol Oceanogr 37(2):252-260

Buskey EJ, Montagna PA, Amos AF, Whitledge TE (1997) Disruption of grazer populations as a contributing factor to the initiation of the Texas brown tide algal bloom. Limnol Oceanogr 42(5/2):1215-1222

Cachon J (1964) Contribution à l'étude des péridiniens parasites. Cytologie, cycles évolutifs. Ann Sci Nat Zool 6:1-158

Cachon J, Cachon M (1987) Parasitic dinoflagellates. In: Taylor FJR (ed) The biology of dinoflagellates. Blackwell Scientific, Oxford, p 571-610

Chatton É, Biecheler B (1935) Les Amoebophrya et les Hyalosaccus: leur cycle évolutif. L'ordre nouveau des Coelomastigines dans les Flagellés. CR Acad Sci Paris 200: 505-507

Christaki U, Dolan JR, Pelegri S, Rassoulzadegan F (1998) Consumption of picoplankton-size particles by marine ciliates: effects of physiological state of the ciliate and particle quality. Limnol Oceanogr 43(3):458-464

Coats DW (1999) Parasitic life styles of marine dinoflagellates. J Eukaryot Microbiol 46(4):402-409

Coats DW, Bockstahler KR (1994) Occurrence of the parasitic dinoflagellate Amoebophrya ceratii in Chesapeake Bay populations of Gymnodinium sanguineum. J Eukaryot Microbiol 41(6):586-593
Coats DW, Heinbokel JF (1982) A study of reproduction and other life cycle phenomena in planktonic protists using an acridine orange fluorescence technique. Mar Biol 67: 71-79

Coats DW, Revelante N (1999) Distributions and trophic implications of microzooplankton. In: Malone T, Malej A, Harding L, Smodlaka N, Turner E (eds) Ecosystems at the landmargin: drainage basin to coastal sea. American Geophysical Union, Washington DC, Coastal and Estuarine Studies Volume 55:207-239

Coats DW, Adam EJ, Gallegos CL, Hedrick S (1996) Parasitism of photosynthetic dinoflagellates in a shallow subestuary of Chesapeake Bay, USA. Aquat Microb Ecol 11: $1-9$

Dolan JR (1991) Guilds of ciliate microzooplankton in the Chesapeake Bay. Estuar Coast Shelf Sci 33:137-152

Dolan JR, Coats DW (1990) Seasonal abundances of planktonic ciliates and microflagellates in mesohaline Chesapeake Bay waters. Estuar Coast Shelf Sci 31:157-175

Elbrächter M (1973) Population dynamics of Ceratium in coastal waters of the Kiel Bay. Oikos Suppl 15:43-48

Fritz L, Nass M (1992) Development of the endoparasitic dinoflagellate Amoebophrya ceratii within host dinoflagellate species. J Phycol 28:312-320

Frost BW (1972) Effect of size and concentration of food particles on the feeding behavior of the marine planktonic copepod Calanus pacificus. Limnol Oceanogr 17:805-815

Granéli E, Sundström B, Edler L, Anderson DM (1987) Toxic marine phytoplankton. Elsevier Science Publishers, New York

Guillard RRL, Ryther JH (1962) Studies on marine planktonic diatoms I. Cyclotella nana Hustedt and Detonula confervacea (Cleve) Gran. Can J Microbiol 8:229-239

Gunderson JH, Goss SH, Coats DW (1999) The phylogenetic position of Amoebophrya sp. infecting Gymnodinium sanguineum. J Eukaryot Microbiol 46(2):194-197

Gunderson JH, Goss SH, Coats DW (2000) rRNA sequence difference among Amoebophrya strains infecting dinoflagellates in Chesapeake Bay. J Eukaryot Microbiol 47:4A

Heinbokel JF (1978) Studies of the functional role of tintinnids in the Southern California Bight. I. Grazing and growth rates in laboratory cultures. Mar Biol 47:177-189

Jacobson DM (1987) The ecology and feeding biology of thecate heterotrophic dinoflagellates. PhD dissertation, WHOI-MIT, Cambridge, MA

Jeong HJ, Latz MI (1994) Growth and grazing rates of the heterotrophic dinoflagellates Protoperidinum spp. on red tide dinoflagellates. Mar Ecol Prog Ser 106:173-185

Jeong HJ, Shim JH, Lee CW, Kim JS, Koh SM (1999a) Growth and grazing rates of the marine planktonic ciliate Strombidinopsis sp. on red-tide and toxic dinoflagellates. J Eukaryot Microbiol 46(1):69-76

Jeong HJ, Shim JH, Kim JS, Park JY, Lee CW, Lee Y (1999b) Feeding by the mixotrophic thecate dinoflagellate Fragilidium cf. mexicanum on red-tide and toxic dinoflagellates. Mar Ecol Prog Ser 176:263-277

Jonsson PR (1986) Particle size selection, feeding rates and growth dynamics of marine planktonic oligotrichous ciliates (Ciliophora: Oligotrichina). Mar Ecol Prog Ser 33:265-277

Kamiyama T (1997) Growth and grazing responses of tintinnid ciliates feeding on the toxic dinoflagellate Heterocapsa circularisquama. Mar Biol 128:509-515

Kim MC, Yoshinaga I, Imai I, Nagasaki K, Itakura S, Ishida Y (1998) A close relationship between algicidal bacteria and termination of Heterosigma akashiwo (Raphidophyceae) blooms in Hiroshima Bay, Japan. Mar Ecol Prog Ser 170: $25-32$ 
Kivi K, Setälä O (1995) Simultaneous measurement of food particle selection and clearance rates of planktonic oligotrich ciliates (Ciliophora: Oligotrichina). Mar Ecol Prog Ser 119:125-137

Lebour MV (1925) The dinoflagellates of Northern Seas. The Mayflower Press, William Brendon \& Son, Plymouth, MA

Lessard EJ (1991) The trophic role of heterotrophic dinoflagellates in diverse marine environments. Mar Microb Food Webs 5(1):49-58

Lessard EJ, Swift E (1985) Species-specific grazing rates of heterotrophic dinoflagellates in oceanic waters, measured with a dual-label radioisotope technique. Mar Biol 87(3): 289-296

Maranda L (2001) Infection of Prorocentrum minimum (Dinophyceae) by the parasite Amoebophrya sp. (Dinoflagellea). J Phycol 37:245-248

Montagnes DJS, Lynn DH (1993) A quantitative protargol stain (QPS) for ciliates and other protists. In: Kemp PF, Sherr BF, Sherr EB, Cole JJ (eds) Handbook of methods in aquatic microbial ecology. Lewis Publishers, Boca Raton, p 229-240

Nagasaki K, Tarutani K, Yamaguchi M (1999) Growth characteristics of Heterosigma akashiwo virus and its possible use as a microbiological agent for red tide control. Appl Environ Microbiol 65(3):898-902

Nishitani L, Erickson G, Chew KK (1985) Role of the parasitic dinoflagellate Amoebophrya ceratii in control of Gonyaulax catenella populations. In: Anderson DM, White AW, Baden DG (eds) Toxic dinoflagellates. Elsevier Science Publishers, New York, p 225-230

Norén F, Moestrup Ø, Rehnstam-Holm AS (1999) Parvilu-

Editorial responsibility: David Caron,

Los Angeles, California, USA cifera infectans Norén et Moestrup gen. et sp. nov. (Perkinsozoa phylum nov.): a parasitic flagellate capable of killing toxic microalgae. Eur J Protistol 35:233-254

Paerl HW (1997) Coastal eutrophication and harmful algal blooms: importance of atmospheric deposition and groundwater as 'new' nitrogen and other nutrient sources. Limnol Oceanogr 42(5/2):1154-1165

Richardson K (1997) Harmful or exceptional phytoplankton blooms in the marine ecosystem. Adv Mar Biol 31:301-385

Smalley GW, Coats DW, Adam EJ (1999) A new method using fluorescent microspheres to determine grazing on ciliates by the mixotrophic dinoflagellate Ceratium furca. Aquat Microb Ecol 17:167-179

Smayda TJ (1997) Harmful algal blooms: their ecophysiology and general relevance to phytoplankton blooms in the sea. Limnol Oceanogr 42(5/2):1137-1153

Steidinger KA, Haddad K (1981) Biologic and hydrographic aspects of red tides. BioScience 31:814-819

Taylor FJR (1968) Parasitism of the toxin-producing dinoflagellate Gonyaulax catenella by the endoparasitic dinoflagellate Amoebophrya ceratii. J Fish Res Board Can 25(10): 2241-2245

Watras CJ, Garcon VC, Olson RJ, Chrisholm SW, Anderson DM (1985) The effect of zooplankton grazing on estuarine blooms of the toxic dinoflagellate Gonyaulax tamarensis. J Plankton Res 7:891-908

Yih W, Coats DW (2000) Infection of Gymnodinium sanguineum by the dinoflagellate Amoebophrya sp.: effect of nutrient environment on parasite generation time, reproduction, and infectivity. J Eukaryot Microbiol 47(5): $504-510$

Submitted: July 18, 2001; Accepted: January 17, 2002 Proofs received from author(s): April 9, 2002 